\title{
Identyczne oferty w postępowaniu o udzielenie zamówienia publicznego
}

\section{Wprowadzenie}

Celem postępowania o udzielenie zamówienia publicznego jest dokonanie wyboru jednej, najkorzystniejszej oferty. Z art. 91 ust. 1 obowiązującej Ustawy z 29 stycznia 2004 r. - Prawo zamówień publicznych ${ }^{1}$ wynika, że zamawiający wybiera ofertę najkorzystniejszą na podstawie kryteriów oceny ofert określonych w specyfikacji istotnych warunków zamówienia. Wydawać by się mogło, że nie jest możliwe, aby w postępowaniu o udzielenie zamówienia publicznego zostały złożone tak samo najkorzystniejsze oferty. Jest jednak inaczej. W praktyce zdarzają się sytuacje, w których zostaje złożona więcej niż jedna oferta najkorzystniejsza dla zamawiającego. Dotyczy to zarówno postępowań, w których zamawiający ustalił jedno kryterium oceny ofert, tj. cenę (lub koszt), jak i postępowań, w których jako kryteria oceny ofert zamawiający ustalił zarówno cenę (lub koszt), jak i inne kryteria odnoszące się do przedmiotu zamówienia. Może się więc zdarzyć, że co najmniej dwie oferty przedstawiają taki sam bilans ceny (lub kosztu) i innych kryteriów odnoszących się do przedmiotu zamówienia, zaś ceny (lub koszt) są takie same, bądź też złożono oferty z takimi samymi najniższymi cenami lub kosztem. W takich sytuacjach oferty te są w równym stopniu najkorzystniejsze ekonomicznie dla zamawiającego. Nie jest jednak możliwe dokonanie wyboru kilku ofert. Celem postępowania jest dokonanie wyboru jednej oferty.

${ }^{1}$ Tekst jedn. Dz.U. 2017, poz. 1579, dalej „ustawa” lub „P.z.p.”. 


\section{Rozwiązania obowiązujące we wcześniejszym stanie prawnym}

Analiza przepisów P.z.p. w brzmieniu obowiązującym przed 28 lipca 2016 r., tj. przed wejściem w życie Ustawy z dnia 22 czerwca 2016 r. o zmianie ustawy - Prawo zamówień publicznych oraz niektórych innych ustaw ${ }^{2}$, nie wskazywała jednoznacznego rozwiązania powyższego problemu. We wcześniejszym stanie prawnym przepisy P.z.p. przewidywały tylko jedną sytuację, w której występowały oferty identyczne w zakresie kryteriów ich oceny. Mianowicie art. 91 ust. 5 tej ustawy w brzmieniu obowiązującym przed nowelizacją z 2016 r. stanowił, że jeżeli w postępowaniu o udzielenie zamówienia, w którym jedynym kryterium oceny ofert jest cena, nie można dokonać wyboru oferty najkorzystniejszej ze względu na to, że zostały złożone oferty o takiej samej cenie, zamawiający wzywa wykonawców, którzy złożyli te oferty, do złożenia w terminie określonym przez zamawiającego ofert dodatkowych. $W$ takim przypadku zamawiający miał obowiązek przeprowadzenia tzw. „dogrywki”, czyli wezwania wykonawców do złożenia ofert dodatkowych. Nie można było jednak wykluczyć sytuacji, w której także oferty dodatkowe były identyczne. Obowiązujące przed nowelizacją przepisy wskazywały jednak rozwiązanie w takiej sytuacji, albowiem art. 93 ust. 1 pkt 5 ustawy stanowił, że jeżeli złożono oferty dodatkowe o takiej samej cenie, zamawiający miał obowiązek unieważnić postępowanie. Przepis ten dotyczył jednak wyłącznie postępowania, w którym jedynym kryterium oceny ofert była cena. Tymczasem oferty z taką samą ceną i liczbą punktów zdarzały się również w postępowaniach, w których oprócz ceny zamawiający określił także inne kryteria oceny ofert. Przepisy ustawy nie dawały wszakże jednoznacznej odpowiedzi, jak powinien postąpić zamawiający w takim przypadku.

Sytuacja ta powodowała rozbieżności w piśmiennictwie. Według jednego ze stanowisk zamawiający powinien postępowanie unieważnić ${ }^{3}$, choć zauważano, że rozwiązanie to budzi wątpliwości ze względu

${ }^{2}$ Ustawa z dnia 22 VI 2016 r. o zmianie ustawy - Prawo zamówień publicznych oraz niektórych innych ustaw (Dz.U. poz. 1020).

${ }^{3}$ J. Pieróg, Prawo zamówień publicznych. Komentarz, Warszawa 2015, s. 364; A. Adach-Nerwińska, Oferta dodatkowa, "Przetargi Publiczne” 2012, nr 7, s. 21; J.E. Nowicki, Prawo zamówień publicznych. Komentarz, Warszawa 2015, s. 839. 
na brak jednoznacznej podstawy do takiego unieważnienia ${ }^{4}$. Innym proponowanym rozwiązaniem było zastosowanie per analogiam art. 91 ust. 5 ustawy i wzywanie wykonawców do złożenia ofert dodatkowych ${ }^{5}$. Rozwiązanie to było w doktrynie krytykowane ${ }^{6}$ przez zwolenników poglądu przychylającego się do koncepcji unieważnienia postępowania. Na gruncie poprzednio obowiązującego stanu prawnego w doktrynie zgodnie wskazywano, że w zakresie tym istniała luka, bowiem przepisy nie określały sposobu postępowania przez zamawiającego w omawianej sytuacji. Rozbieżności wzbudzał sposób postępowania w tym przypad$\mathrm{ku}$, a mianowicie to, czy zamawiający powinien był postąpić w wyżej wymieniony sposób, czy też powinien zwrócić się do wykonawców o złożenie ofert dodatkowych. Kontrowersje wywoływał więc sposób uzupełnienia owej luki prawnej.

Rozważając zasadność powyższych rozwiązań, należy zwrócić uwagę na kilka argumentów przemawiających za lub przeciw każdemu z nich, które zostaną przedstawione poniżej.

\section{Unieważnienie postępowania}

W doktrynie podnoszono, że skoro ustawodawca nie przewidział wprost w omawianej sytuacji procedury składania ofert dodatkowych, to postępowanie należało unieważnić na podstawie art. 93 ust. 1 pkt 7 ustawy, tj. z powodu nieusuwalnej wady postępowania, która uniemożliwia zawarcie niepodlegającej unieważnieniu umowy w sprawie zamówienia publicznego ${ }^{7}$. Takie stanowisko zostało także zajęte w orzecznictwie Zespołu Arbitrów przy Urzędzie Zamówień Publicznych. W postanowieniu Zespołu Arbitrów z dnia 10 lipca 2006 r. (UZP/ZO/0-1947/06) $)^{8}$ stwierdzono, że instytucja składania ofert dodatkowych określona w art. 91 ust. 5 ustawy - Prawo zamówień publicznych nie znajduje zastosowania w sytuacji, gdy jedynym kryterium oceny nie było kryterium ceny w postępowaniu, i wobec faktu złożenia dwóch ofert najkorzystniejszych

\footnotetext{
${ }^{4}$ A. Gawrońska-Baran, Unieważnienie przetargu nieograniczonego na zamówienie publiczne, Warszawa 2014, s. 107.

${ }^{5}$ S. Babiarz, Prawo zamówień publicznych. Komentarz, Warszawa 2011, s. 504.

${ }^{6}$ J. Pieróg, op. cit., s. 364; J.E. Nowicki, op. cit., s. 839; A. Adach-Nerwińska, op. cit., s. 21; A. Gawrońska-Baran, op. cit., s. 107.

${ }^{7}$ A. Gawrońska-Baran, op. cit., s. 107; A. Adach-Nerwińska, op. cit., s. 21.

${ }^{8}$ LEX nr 241017.
} 
nakazano unieważnienie postępowania. W ocenie Zespołu Arbitrów brak możliwości wybrania jednej oferty najkorzystniejszej należało traktować jako wadę postępowania uniemożliwiającą zawarcie ważnej umowy w sprawie zamówienia publicznego i skutkującą obowiązkiem unieważnienia postępowania na podstawie art. 93 ust. 1 pkt 7 ustawy Prawo zamówień publicznych.

Istotne było jednak, czy w takim przypadku rzeczywiście występowała wada postępowania, o której mowa w przepisie art. 93 ust. 1 pkt 7 P.z.p. Krajowa Izba Odwoławcza w wyroku z 11 kwietnia 2013 r. (KIO $741 / 13)^{9}$ wyjaśniła, że „przesłanka unieważnienia postępowania określona w tym przepisie składa się z koniunkcji trzech okoliczności, których łączne wystąpienie skutkuje koniecznością zastosowania przepisu. Po pierwsze musi wystąpić naruszenie przepisów ustawy regulujących udzielanie zamówienia (wada postępowania). Po drugie wada ta ma skutkować niemożliwością zawarcia niepodlegającej unieważnieniu umowy w sprawie zamówienia publicznego. [...]. Po trzecie wada ta musi być niemożliwa do usunięcia". Aby możliwe było wystąpienie wady postępowania, konieczne było więc naruszenie przepisów P.z.p. skutkujące możliwością unieważnienia umowy. Przesłanka ta powiązana była z okolicznościami stanowiącymi podstawę do unieważnienia umowy.

Przypadki naruszenia przepisów postępowania, które zarówno przed wejściem w życie nowelizacji z dnia 22 czerwca 2016 r., jak i obecnie, stanowią podstawę do unieważnienia umowy, określa przepis art. 146 ust. 1 P.z.p. W doktrynie i orzecznictwie Krajowej Izby Odwoławczej ukształtował się pogląd, że podstawą do unieważnienia postępowania są także naruszenia opisane $\mathrm{w}$ art. 146 ust. 6 P.z.p., a mianowicie dokonanie przez zamawiającego czynności lub zaniechanie dokonania czynności z naruszeniem przepisu ustawy, które miało lub mogło mieć wpływ na wynik postępowania. Żadna z tych przesłanek nie zachodziła jednak w omawianej sytuacji. Nie ulega wątpliwości, że nie był to żaden z przypadków wymienionych w art. 146 ust. 1 P.z.p. Nie mieliśmy do czynienia także z naruszeniem przepisu ustawy, o którym mowa w art. 146 ust. 6 P.z.p., tj. dokonaniem przez zamawiającego czynności lub zaniechaniem dokonania czynności z naruszeniem przepisu P.z.p., które mogłoby zostać zakwalifikowane jako wada postępowania, albowiem nie występowało wadliwe zachowanie zamawiającego. Złożenie ofert identycznych $\mathrm{w}$ zakresach podlegających ocenie to czynności

\footnotetext{
${ }^{9}$ Legalis nr 741605.
} 
wykonawców i nie stanowią one naruszenia przepisu ustawy. Prawidłowość unieważnienia postępowania na tej podstawie prawnej wzbudzała wątpliwości ${ }^{10}$. Zwracano również uwagę, że przepisy ustawy - Prawo zamówień publicznych zawierają zamknięty katalog przesłanek unieważnienia postępowania, który jest określony w art. 93 tego aktu.

Ponadto ustawa nakazuje unieważnienie postępowania, m.in. jeżeli w przypadkach, o których mowa w art. 91 ust. 5 P.z.p., zostały złożone oferty dodatkowe o takiej samej cenie (art. 93 ust. 1 pkt 5 P.z.p.). Uwagę zwraca to, że sam ustawodawca nie potraktował braku możliwości wyboru najkorzystniejszej oferty w omawianej sytuacji jako wady postępowania. Gdyby było inaczej, zbędny byłby przepis art. 93 ust. 1 pkt 5 P.z.p., a wystarczającą podstawę prawną do unieważnienia postępowania stanowiłby przepis art. 93 ust. 1 pkt 7 P.z.p.

Wobec powyższego nie można było uznać za trafne przyjęcia, że w omawianej sytuacji mieliśmy do czynienia $\mathrm{z}$ wadą postępowania usprawiedliwiającą unieważnienie postępowania na podstawie art. 93 ust. 1 pkt 7 P.z.p.

W doktrynie wyrażono także pogląd, że w takiej sytuacji brak jest zarówno podstaw do przyjęcia, że zachodzi wada postępowania uzasadniająca unieważnienie postępowania, jak i że brak jest podstaw do wezwania wykonawców do złożenia ofert dodatkowych. W podobnej sytuacji, tj. braku ofert dodatkowych, wskazano, że rozwiązaniem mogłoby być unieważnienie na podstawie innych przesłanek, np. upływu terminu związania ofertą czy upływu ważności wadium ${ }^{11}$. Dopuszczalność unieważnienia postępowania $\mathrm{w}$ takich przypadkach jest także wątpliwa i znajduje wyraz w rozbieżnym orzecznictwie Krajowej Izby Odwoławczej ${ }^{12}$. W orzecznictwie tym kwestionuje się możliwość unieważnienia postępowania z powodu upływu terminu związania oferta, wskazując, że okoliczność ta nie jest wadą postępowania. Stanowisko Prezesa Urzędu Zamówień Publicznych jest z tym poglądem zbieżne. Wskazuje się też jednak, że „wybór oferty po upływie terminu związania

${ }^{10}$ J. Pieróg op. cit., s. 364; A. Adach-Nerwińska, op. cit., s. 21; J.E. Nowicki, op. cit., s. 839; A. Gawrońska-Baran, op. cit., s. 107.

${ }^{11}$ Tak W. Dzierżanowski, Komentarz do art. 93 ustawy Prawo zamówień publicznych, w: M. Stachowiak, J. Jerzykowski, W. Dzierżanowski, Prawo zamówień publicznych. Komentarz, Warszawa 2014, s. 517.

${ }^{12}$ Uchwała Krajowej Izby Odwoławczej (KIO) z dnia 5 VII 2010 r., sygn. KIO/KD 46/10, Legalis nr 758178; wyrok KIO z 19 X 2010 r., sygn. KIO 2204/10, Legalis nr 365323; wyrok KIO z 2 IV 2013 r., sygn. KIO 655/13, Legalis nr 742217; uchwała KIO z 2 XI 2012 r., sygn. KIO/KD 85/12, Legalis nr 750241. 
ofertą stanowi naruszenie przepisów ustawy, które miało lub mogło mieć wpływ na wynik postępowania. Umowa o wykonanie zamówienia zawarta w wyniku takiego wyboru byłaby dotknięta wadą - nieważnością względną, uprawniającą Prezesa Urzędu Zamówień Publicznych do wystąpienia do sądu o jej unieważnienie zgodnie z art. 146 ust. 6 Ustawy z dnia 29 stycznia 2004 r. - Prawo zamówień publicznych (t.j. Dz.U. z 2015 r. poz. 2164 ze zm.). Okoliczności te odpowiadają przesłankom obarczenia postępowania wada, o której stanowi przepis art. 93 ust. 1 pkt 7 ustawy"13.

\section{Wezwanie do złożenia ofert dodatkowych}

Innym rozwiązaniem omawianej sytuacji zaproponowanym na gruncie obowiązującego do 2016 r. stanu prawnego było wezwanie wykonawców do złożenia ofert dodatkowych na podstawie stosowanego w drodze analogii przepisu art. 91 ust. 5 ustawy. Założeniem tego przepisu było przeprowadzenie tzw. dogrywki pomiędzy wykonawcami, w ofertach których ceny były takie same. Z jego literalnego brzmienia wynikało jednak, że dotyczył on postępowania, w którym jedynym kryterium jest cena. Ustawodawca wprawdzie przewidział możliwość złożenia dwóch lub więcej ofert najkorzystniejszych w postępowaniu, w którym cena nie jest jedynym kryterium, tj. $z$ takim samym bilansem ceny $i$ innych kryteriów oceny ofert, nakazując zamawiającemu wybranie oferty z niższą ceną (art. 91 ust. 4 P.z.p.), jednakże nie przewidział, że oferty mogą być identyczne we wszystkich elementach podlegających ocenie w ramach ustalonych kryteriów oceny ofert, a więc także co do ceny.

Na gruncie stanu prawnego obowiązującego przed nowelizacją z 2016 r. wydawało się celowe stosowanie w drodze analogii tego przepisu również $\mathrm{w}$ sytuacji złożenia ofert $\mathrm{z}$ takim samym bilansem punktów za wszystkie kryteria oceny ofert, tj. ceny i kryteria pozacenowe, oraz takimi samymi cenami. Brak było racjonalnego argumentu przemawiającego przeciwko dopuszczalności złożenia ofert dodatkowych w postępowaniu, w którym przewidziano różne kryteria oceny ofert w sytuacji, gdy możliwość taka została dopuszczona w postępowaniu, w którym jedynym kryterium oceny ofert jest cena. Za taką interpretacją przemawiał także fakt, że stanowisko wskazujące, iż sytuacja taka jest

${ }^{13}$ Wyrok KIO z 6 XII 2016 r., sygn. KIO 2206/16, Legalis nr 1560128; wyrok KIO z 6 VI 2016 r., sygn. KIO 883/16, Legalis nr 1501596. 
wadą postępowania, nie było przekonujące. Przeciwko takiej propozycji wysuwany był argument, że zamawiający nie został upoważniony do wezwania wykonawców do złożenia ofert dodatkowych. Jednakże słabością tej argumentacji było jednak to, że ustawodawca nie określił także konsekwencji niezłożenia przez wykonawców ofert dodatkowych, a mimo to w doktrynie wskazywano na dopuszczalność unieważnienia przez zamawiającego postępowania $\mathrm{w}$ takiej sytuacji na podstawie stosowanego per analogiam przepisu art. 93 ust. 1 pkt 5 P.z.p. ${ }^{14}$

Biorąc pod uwage powyższe, w stanie prawnym obowiązującym przed wyżej wymienioną nowelizacją P.z.p. należało zastosować w drodze analogii normę art. 91 ust. 5 ustawy - Prawo zamówień publicznych i wezwać wykonawców do złożenia ofert dodatkowych. Dopiero w przypadku złożenia identycznych ofert dodatkowych zamawiający byłby zobligowany unieważnić postępowanie na podstawie art. 93 ust. 1 pkt 5 P.z.p. Rozwiązanie to nie jest jednak pozbawione wad, albowiem przepis ten odnosi się jedynie do ofert dodatkowych identycznych w zakresie ceny. Postępowanie takie było korzystniejsze dla zamawiającego niż unieważnienie postępowania, gdyż służyło osiągnięciu celu, dla jakiego było ono prowadzone, tj. dokonaniu wyboru najkorzystniejszej oferty i udzieleniu zamówienia publicznego. Odmienny pogląd został wyrażony jednak w wyroku Krajowej Izby Odwoławczej z 11 marca 2010 r. (sygn. KIO/UZP 163/10) ${ }^{15}$, w którym uznano, że zamawiający, dokonując czynności wezwania do złożenia ofert dodatkowych, narusza art. 191 ust. 5 ustawy, skoro z dyspozycji tego przepisu skorzystać można wyłącznie w sytuacji, gdy jedynym kryterium oceny ofert jest cena. Krajowa Izba Odwoławcza w wyroku tym uznała, że czynność wezwania do złożenia ofert dodatkowych dokonana przez zamawiającego narusza prawo. $W$ dalszym ciągu nie byłby jednak rozwiązany problem braku ofert dodatkowych.

Każdy sposób rozwiązania powyższego problemu nie był pozbawiony słabych stron. Postulatem de lege ferenda było jasne określenie przez ustawodawcę sposobu postępowania w sytuacji, gdy dwie lub więcej ofert przedstawia taki sam bilans ceny i innych kryteriów oceny ofert, a ceny są jednakowe. Ustawa P.z.p. wymagała w tym zakresie poprawy. Nowelizacja ustawy P.z.p. uchwalona w dniu 22 czerwca 2016 r. jedynie częściowo sprostała tym potrzebom.

\footnotetext{
${ }^{14}$ A. Gawrońska-Baran, op. cit., s. 114.

${ }^{15}$ Legalis nr 797619.
} 


\section{Rozwiązania przyjęte w projekcie ustawy - Prawo zamówień publicznych}

Powyższe rozważania poczynione zostały na gruncie obowiązujących przed nowelizacją z 2016 r. przepisów ustawy - Prawo zamówień publicznych. Wspomnieć należy, że niezależnie od prac związanych z nowelizacją ustawy wcześniej zaczęły się prace nad projektem nowej ustawy - Prawo zamówień publicznych ${ }^{16}$. Wprawdzie do uchwalenia tego projektu nie doszło, celowe jest jednak przeanalizowanie projektowanych rozwiązań pod kątem omawianego problemu.

Lektura projektu ustawy - Prawo zamówień publicznych nie tylko nie przynosi jednoznacznego rozwiązania, lecz także rodzi wątpliwości co do tego, jak powinien postąić zamawiający w sytuacji, gdy zostały złożone oferty identyczne $\mathrm{w}$ kryteriach podlegających ocenie, a więc oferty równie najkorzystniejsze ekonomicznie dla zamawiającego.

W pierwszej kolejności zwrócić należy uwagę, że projekt ten nie zawierał przepisu odpowiadającego przepisowi art. 91 ust. 5 obecnie obowiązującej regulacji. Nie zawierał on w ogóle normy dedykowanej dla sytuacji, w której zamawiający ma do czynienia z identycznymi ofertami najkorzystniejszymi dla niego ekonomicznie. Jak w takiej sytuacji powinien postąpić zamawiający według projektowanych regulacji? Odpowiedź na to pytanie nie jest oczywista.

Przepisy projektu nie dawały zamawiającemu możliwości wezwania wykonawców do złożenia ofert dodatkowych w żadnej sytuacji. Odpadałaby więc możliwość zastosowania w tym przypadku w drodze analogii innego przepisu ustawy zezwalającego na składanie ofert dodatkowych. Czy więc zamawiający w takiej sytuacji powinien unieważnić postępowanie?

Projektowane regulacje rozszerzały możliwość unieważnienia postępowania przez zamawiającego. Przepis art. 115 ust. 1 projektu ustawy zawierał obligatoryjne przesłanki unieważnienia postępowania, za które uznawał: brak oferty albo wniosku o dopuszczenie do udziału w postępowaniu, odrzucenie wszystkich ofert albo wniosków o dopuszczenie do udziału w postępowaniu, wyraźny brak możliwości zaspokojenia

${ }^{16}$ Projekt ustawy - Prawo zamówień publicznych z 12 X 2015 r. przyjęty z autopoprawką przez Radę Ministrów w dniu 27 X 2015 r., znajdujący się w Archiwalnym wykazie prac legislacyjnych i programowych Rządowego Centrum Legislacji pod numerem UC158, Rządowe Centrum Legislacji, http://legislacja.rcl.gov.pl/projekt/12271652/ katalog/12284995\#12284995 (dostęp: 31 VII 2018). 
potrzeb i spełnienia wymogów zamawiającego określonych w dokumentach zamówienia przez żadną z ofert bez istotnych zmian w tych ofertach. Przepis ten nie mógłby stanowić podstawy do unieważnienia postępowania w omawianej sytuacji.

Przepis art. 115 ust. 2 projektu ustawy stanowił, że zamawiający może unieważnić postępowanie o udzielenie zamówienia publicznego, jeśli zachodzą inne obiektywnie uzasadnione przesłanki, w szczególności wystąpiła istotna zmiana okoliczności powodująca, że prowadzenie postępowania lub wykonanie zamówienia publicznego nie leży w interesie publicznym, lub postępowanie obarczone jest niemożliwą do usunięcia wadą uniemożliwiającą zawarcie niepodlegającej unieważnieniu umowy w sprawie zamówienia publicznego. Przepis ten zawiera otwarty katalog okoliczności stanowiących podstawę unieważnienia postępowania, albowiem mogą to być obiektywnie uzasadnione przesłanki. Zawarte w tym przepisie wyliczenie jest jedynie przykładowe i stanowi regulację prawną analogiczną do obecnie obowiązującego przepisu art. 145 P.z.p. oraz art. 93 ust. 1 pkt 7 P.z.p. Wydaje się, że na gruncie projektu ustawy zasadne byłoby unieważnienie postępowania z powodu braku możliwości dokonania wyboru oferty w przypadku złożenia dwóch lub więcej ofert najkorzystniejszych ekonomicznie, ale nie z powodu niemożliwej do usunięcia wady postępowania uniemożliwiającej zawarcie niepodlegającej unieważnieniu umowy w sprawie zamówienia publicznego.

Wskazać także należy, że przepis art. 115 ust. 2 projektu ustawy stanowił, iż zamawiający "może” unieważnić postępowanie, co sugeruje, że nie są to przesłanki obligatoryjnego unieważnienia postępowania. Co ciekawe, w postępowaniu dotkniętym nieusuwalną wada, która uniemożliwia zawarcie niepodlegającej unieważnieniu umowy, zamawiający nie byłby zobligowany do unieważnienia postępowania. Jest to sytuacja odmienna od obecnie obowiązującej regulacji, gdyż na gruncie aktualnych przepisów w razie wystąpienia przesłanek unieważnienia postępowania zamawiający zobowiązany jest to uczynić.

Projektowane rozwiązania nie wprowadzały unormowań eliminujących w całości istniejące wcześniej problemy. Projekt ten nie został zresztą uchwalony. $\mathrm{W}$ dalszym ciągu aktualne sa postulaty wprowadzenia rozwiązań w tym zakresie. Racjonalne byłoby wprowadzenie rozwiązań dających zamawiającemu szansę na dokonanie wyboru najkorzystniejszej oferty i udzielenie zamówienia poprzez umożliwienie zamawiającemu wzywania do złożenia ofert dodatkowych w sytuacji, gdy złożone oferty są identyczne w kryteriach podlegających ocenie. 
Dopiero w sytuacji, gdy w wyniku wezwania do złożenia ofert dodatkowych nadal nie byłoby możliwe dokonanie wyboru najkorzystniejszej oferty, zamawiający miałby podstawy do unieważnienia postępowania. Rozwiązanie takie nie narusza reguł uczciwej konkurencji i równego traktowania wykonawców.

\section{Rozwiązania przyjęte w nowelizacji ustawy P.z.p.}

Wobec sygnalizowanych $\mathrm{w}$ doktrynie watpliwości co do sposobu postępowania przez zamawiającego w powyższej sytuacji przy okazji uchwalonej w dniu 22 czerwca 2016 r. nowelizacji ustawy - Prawo zamówień publicznych mającej na celu wdrożenie do polskiego porządku prawnego dyrektyw klasycznej i sektorowej dokonano zmiany art. 91 ustawy, określając czynności podejmowane przez zamawiającego $\mathrm{w}$ przypadku złożenia identycznych ofert. $\mathrm{W}$ nowych rozwiązaniach wprowadzono obowiązek zamawiającego wezwania wykonawców do złożenia ofert dodatkowych.

Przechodząc do rozważań dotyczących znowelizowanych przepisów ustawy, na wstępie wskazać należy, że w ustawie dokonano istotnej zmiany definicji najkorzystniejszej oferty. Obecnie jest nią oferta przedstawiająca najkorzystniejszy bilans ceny lub kosztu i innych kryteriów odnoszących się do przedmiotu zamówienia publicznego, w szczególności w przypadku zamówień w zakresie działalności twórczej lub naukowej, których przedmiotu nie można z góry opisać w sposób jednoznaczny i wyczerpujący lub która najlepiej spełnia kryteria inne niż cena lub koszt, gdy cena lub koszt jest stała, albo oferta $z$ najniższą ceną lub kosztem, gdy jedynym kryterium oceny jest cena lub koszt. W znowelizowanych przepisach pojawiło się pojęcie kosztu, które może być kryterium oceny oferty zamiast ceny.

Zgodnie ze znowelizowanym w 2016 r. art. 91 ust. 4 ustawy, jeżeli nie można wybrać najkorzystniejszej oferty ze względu na to, że dwie lub więcej ofert przedstawia taki sam bilans ceny lub kosztu i innych kryteriów oceny ofert, zamawiający spośród tych ofert wybiera ofertę z najniższą ceną lub najniższym kosztem, a jeżeli zostały złożone oferty o takiej samej cenie lub koszcie, zamawiający wzywa wykonawców, którzy złożyli te oferty, do złożenia w terminie określonym przez zamawiającego ofert dodatkowych. Natomiast jeżeli w postępowaniu o udzielenie zamówienia, w którym jedynym kryterium oceny ofert jest 
cena lub koszt, nie można dokonać wyboru najkorzystniejszej oferty ze względu na to, że zostały złożone oferty o takiej samej cenie lub koszcie, zamawiający wzywa wykonawców, którzy złożyli te oferty, do złożenia $\mathrm{w}$ terminie określonym przez zamawiającego ofert dodatkowych (art. 91 ust. 5 ustawy). Ustawodawca uregulował tym samym jednoznacznie obowiązek przeprowadzenia tzw. „dogrywki”, nie ograniczając go do postępowania, w którym występuje tylko jedno kryterium oceny ofert, co zdecydowanie należy ocenić pozytywnie.

Dokonując w 2016 r. zmiany art. 91 ustawy, dodano przepis ust. 5a, który dotyczy sytuacji braku możliwości wyboru najkorzystniejszej oferty w postępowaniu o udzielenie zamówienia, w którym jedynym kryterium oceny ofert jest koszt (rozumiany jako suma kosztu nabycia i innych kosztów cyklu życia) z powodu złożenia ofert o takim samym koszcie. Przepis ten zakłada, że w takim przypadku zamawiający wybiera ofertę z niższym kosztem nabycia albo z niższymi innymi kosztami cyklu życia, jeżeli przewidział to w specyfikacji istotnych warunków zamówienia. Istotne jest ustalenie relacji między obowiązkiem wezwania wykonawców do złożenia ofert dodatkowych (art. 91 ust. 5 ustawy) a uprawnieniem zamawiającego do wybrania jednej z ofert, przy czym należy się kierować wysokością kosztu nabycia albo kosztów cyklu życia określonymi w nowym przepisie. Wydaje się, że w takiej sytuacji zamawiający nie jest zwolniony z obowiązku zwrócenia się do wykonawców o złożenie ofert dodatkowych. Jedynie w razie braku możliwości wybrania najkorzystniejszej oferty z powodu złożenia ofert o takim samym koszcie, po uprzednim wezwaniu do złożenia ofert dodatkowych, zamawiający byłby uprawniony do wybrania oferty z niższym kosztem nabycia albo niższymi innymi kosztami cyklu życia, jeżeli taką możliwość wcześniej zastrzegł.

Dokonując powyższych zmian, ustawodawca nie zapewnił jednak spójnej z nimi redakcji art. 93 ust. 1 pkt 5 P.z.p. określającego jedną z przesłanek unieważnienia postępowania. Przepis ten nie uległ zmianie w wyniku nowelizacji ustawy z dnia 22 czerwca 2016 r. Ustawodawca nie tylko nie dostosował jego treści do zmienionej definicji najkorzystniejszej oferty w postępowaniu, w którym kryterium oceny ofert jest koszt, a nie cena, ale również do zmienionego art. 91 ustawy. Dotyczy to zarówno postępowań, w których zamawiający ustalił jedno kryterium oceny ofert, jak i postępowań, w których określono także pozacenowe kryteria oceny ofert. Spowodować to może dla zamawiającego następujące komplikacje. 
Po pierwsze, wynikające $\mathrm{z}$ art. 93 ustawy przesłanki unieważnienia postępowania w dalszym ciągu nie zawierają jednoznacznej podstawy do unieważnienia postępowania w razie złożenia ofert dodatkowych o takiej samej cenie (lub obecnie także koszcie) i liczbie punktów za inne kryteria. Słabością tego przepisu jest to, że nie uwzględnia on nowelizacji ustawy z 22 czerwca 2016 r. w zakresie dotyczącym kryteriów oceny ofert. Mianowicie, wprawdzie odsyła on do art. 91 ust. 5 ustawy odnoszącego się do postępowania z jednym kryterium oceny oferty, tj. ceną lub kosztem, jednakże obowiązek unieważnienia postępowania nakłada w przypadku złożenia ofert dodatkowych w zakresie ceny, a nie kosztu. Ponadto przepis ten nie uwzględnia znowelizowanego art. 91 ust. 4 ustawy przewidującego tzw. dogrywkę także w postępowaniu, w którym kryteriami są cena (lub koszt) i inne kryteria odnoszące się do przedmiotu zamówienia publicznego, która także może zakończyć się albo brakiem ofert dodatkowych, albo złożeniem identycznych ofert dodatkowych. Artykuł 93 ust. 1 pkt 5 nie zawiera odesłania do tego przepisu. Mimo dokonanej nowelizacji art. 91 ustawy i wobec braku zmiany art. 93 ustawy aktualne $\mathrm{w}$ tym zakresie pozostają wątpliwości zgłaszane na gruncie poprzedniego stanu prawnego dotyczące możliwości unieważnienia postępowania w sytuacji złożenia identycznych ofert dodatkowych.

Po drugie, nadal nierozwiązana pozostaje kwestia niezłożenia ofert dodatkowych (wykonawca nie ma bowiem takiego obowiązku). Przepisy ustawy nie dają podstaw do odrzucenia oferty złożonej przez wykonawcę, który nie złożył oferty dodatkowej, ani do jego wykluczenia. Braku złożenia oferty dodatkowej nie można potraktować jako cofnięcia oferty, czynność taka na tym etapie postępowania jest niedopuszczalna. Nie może to także powodować ustania stanu związania oferta, a oferta pierwotna jest nadal ważna. Zaoferowanie cen wyższych niż w złożonych ofertach jest natomiast zabronione (art. 91 ust. 6 ustawy). W takim przypadku zasadne wydaje się przyjęcie, że poprzez niezłożenie oferty dodatkowej wykonawca podtrzymuje pierwotnie złożoną przez siebie ofertę, do czego ma oczywiście prawo. W doktrynie wskazano, że w postępowaniu, w którym jedynym kryterium jest cena, rozwiązaniem wydaje się unieważnienie postępowania na podstawie art. 93 ust. 1 pkt 5 P.z.p. ${ }^{17}$ Przepis ten wprawdzie wprost odnosi się do przypadku złożenia ofert dodatkowych o takiej samej cenie, a nie ich braku, to jednak

\footnotetext{
${ }^{17}$ Tak też A. Adach-Nerwińska, op. cit., s. 20.
} 
zamawiający musi zakończyć postępowanie, a nie może dokonać wyboru dwóch ofert. Jedynym wyjściem w takiej sytuacji, niepozbawionym jednak słabych stron, wydaje się unieważnienie postępowania poprzez zastosowanie per analogiam tej podstawy prawnej ${ }^{18}$. Logiczny jest taki sam sposób postępowania w odniesieniu do postępowań, w których zamawiający ustanowił cenowe i pozacenowe kryteria oceny ofert, co jednakże zasadnie może wzbudzać kontrowersje.

Sytuacje, które mogą wystąić na gruncie omawianych przepisów P.z.p., nadal będą stanowiły problem dla zamawiających, gdyż przyjęte regulacje $\mathrm{w}$ dalszym ciągu nie daja, niestety, jednoznacznego, niebudzącego wątpliwości interpretacyjnych rozwiązania i wymagają poprawy. Postulatem de lege ferenda jest wprowadzenie niewywołującej rozbieżności interpretacyjnych podstawy prawnej do unieważnienia postępowania w przypadku niezłożenia ofert dodatkowych oraz złożenia identycznych ofert dodatkowych nie tylko w zakresie ceny, ale także kosztu oraz w postępowaniu, w którym ustanowiono również pozacenowe kryteria oceny ofert.

\section{Identyczne oferty a porozumienia ograniczające konkurencję}

Określenie prawidłowego sposobu postępowania przez zamawiającego w sytuacji otrzymania identycznych ofert może mieć nie tylko wymiar ściśle proceduralny i ograniczający się do wyboru najkorzystniejszej oferty czy unieważnienia postępowania. Wprawdzie celem tego postępowania jest wyłonienie najkorzystniejszej oferty, to jednak równie istotne jest jego przeprowadzenie $\mathrm{z}$ zachowaniem zasad uczciwej konkurencji i umożliwienie wykonawcom uczestniczenia w nim w warunkach współzawodnictwa. Porozumienia powodujące zachwianie mechanizmów konkurencji są niedozwolone i mogą rodzić konsekwencje dla wykonawców zarówno karne, jak i przewidziane przez ustawodawcę na gruncie prawa zamówień publicznych czy Ustawy z dnia 16 lutego 2007 r. o ochronie konkurencji i konsumentów ${ }^{19}$.

Otrzymanie przez zamawiającego takich samych, a nawet bardzo podobnych ofert, zwłaszcza w przypadkach, gdy określono więcej niż jedno kryterium oceny ofert, może być sygnałem, że wykonawcy zawarli

\footnotetext{
18 Tak też A. Gawrońska-Baran, op. cit., s. 114.

${ }^{19}$ Tekst jedn. Dz.U. 2018, poz. 798.
} 
niedozwolone porozumienie w celu wpłynięcia na wynik postępowania o udzielenie zamówienia publicznego.

Zachowanie powyższe może spotkać się z sankcją karna, albowiem zgodnie z art. $305 \S 1$ Kodeksu karnego ${ }^{20}$ karalne jest udaremnianie lub utrudnianie przetargu publicznego albo wchodzenie w porozumienie z inną osoba, działając na szkodę osoby lub instytucji, na rzecz której przetarg jest dokonywany, jeżeli jest podejmowane w celu osiągnięcia korzyści majątkowej. Ponadto możliwa jest także sankcja administracyjna w postaci obowiązku zapłaty przez wykonawców kary pieniężnej, do nałożenia której uprawniony jest Prezes Urzędu Ochrony Konkurencji i Konsumentów w oparciu o przepisy przywołanej ustawy o ochronie konkurencji i konsumentów. Zgodnie z art. 6 ust. 1 pkt 7 tego aktu zakazane są porozumienia, których celem lub skutkiem jest wyeliminowanie, ograniczenie lub naruszenie $w$ inny sposób konkurencji na rynku właściwym, polegające na uzgadnianiu przez przedsiębiorców przystępujących do przetargu lub przez tych przedsiębiorców i przedsiębiorcę będącego organizatorem przetargu warunków składanych ofert, w szczególności zakresu pracy i ceny.

Odpowiedzialność karna i administracyjna, o której mowa, to nie jedyne możliwe konsekwencje zawarcia takich zabronionych porozumień. Fakt poczynienia przez wykonawców niedozwolonych uzgodnień nie pozostaje bez wpływu na sposób postępowania przez zamawiającego. Ma on bowiem w określonych przypadkach obowiązek wykluczenia wykonawcy lub odrzucenia jego oferty. W zależności od okoliczności dojść może także do zatrzymania przez zamawiającego wadium na podstawie art. 46 ust. 4 a P.z.p.

Do czasu wejścia w życie w 2016 r. nowelizacji przepisów prawa zamówień publicznych zamawiający miał jedną podstawę do odrzucenia ofert wykonawców, którzy zawierali niedozwolone porozumienia ograniczające konkurencję, zawartą w art. 89 ust. 1 pkt 3 ustawy. W myśl tego przepisu, nadal zresztą obowiązującego, zamawiający odrzuca ofertę, jeżeli jej złożenie stanowi czyn nieuczciwej konkurencji w rozumieniu przepisów o zwalczaniu nieuczciwej konkurencji. Czynem tym jest działanie sprzeczne z prawem lub dobrymi obyczajami, jeżeli zagraża lub narusza interes innego przedsiębiorcy lub klienta (art. 3 ust. 1 Ustawy z dnia 16 kwietnia 1993 r. o zwalczaniu nieuczciwej

${ }^{20}$ Ustawa z dnia 6 VI 1997 r. Kodeks karny (tekst jedn. Dz.U. 2018, poz. 1600), dalej „k.k.". 
konkurencji $\left.{ }^{21}\right)$. W wyniku dokonanej w 2016 r. nowelizacji prawa zamówień publicznych oprócz podstawy do odrzucenia oferty rozszerzono określone w art. 24 ustawy podstawy wykluczenia wykonawcy o takie, które są związane z zawieraniem niedozwolonych porozumień ograniczających konkurencję. W obecnym stanie prawnym podstawa wykluczenia wykonawcy zachodzi m.in. w przypadku jego prawomocnego skazania (jeżeli jest osobą fizyczną) za przestępstwo, o którym mowa w art. 305 k.k. (art. 24 ust. 1 pkt 13 lit. a ustawy). Ponadto zamawiający zobligowany jest wykluczyć z postępowania także wykonawcę, który z innymi wykonawcami zawarł porozumienie mające na celu zakłócenie konkurencji między wykonawcami w postępowaniu o udzielenie zamówienia, co zamawiający jest w stanie wykazać za pomocą stosownych środków dowodowych (art. 24 ust. 1 pkt 20 ustawy). Na gruncie tego przepisu zamawiający może jednak napotkać istotne trudności dowodowe w wykazaniu, że wykonawcy zawarli porozumienie w celu zachwiania konkurencyjności. Ciężar udowodnienia, że doszło do zawarcia takiego porozumienia i jego celu, spoczywa na zamawiającym. W kwestii tej powinien on brać pod uwagę całokształt okoliczności mogących świadczyć o dokonaniu między wykonawcami takich uzgodnień. Mogą to być fakty bezpośrednio o tym świadczące, np. pisemne porozumienie, choć będą one jednak trudne do uzyskania, bowiem wykonawcy, dążąc do zachowania w tajemnicy takich ustaleń, będą czynili je ustnie. Na praktyczną niemożliwość przedstawienia takiego dowodu zwrócił uwagę Sąd Najwyższy w wyroku z 9 sierpnia 2006 r. (sygn. III SK 6/06 22 ${ }^{22}$. Dopuszczalne są też takie dowody, które jedynie w sposób pośredni, poszlakowy wskazują na poczynienie przez wykonawców niedozwolonych uzgodnień. Okoliczności wskazujących na zawarcie takiej zabronionej umowy może być wiele, np. złożenie identycznych ofert, podobne braki w ofertach czy ich szata graficzna, składanie ofert i ich uzupełnień bądź wyjaśnień w tym samym czasie, a nawet wręcz przez tę samą osobę, lub odręczne wypełnianie formularzy różnych wykonawców przez tę samą osobę, a także różnego rodzaju powiązania między wykonawcami. W ocenie Urzędu Zamówień Publicznych dowodem zawarcia takiego porozumienia może być decyzja Prezesa Urzędu Ochrony Konkurencji i Konsumentów, a także wyrok sądu

${ }^{21}$ Tekst jedn. 2018, poz. 419 ze zm.

${ }^{22}$ OSNP 2008, nr 1-2, poz. 25, Dz.Urz. Urzędu Ochrony Konkurencji i Konsumentów 2007 Nr 3, poz. 39. 
powszechnego czy Krajowej Izby Odwoławczejej ${ }^{23}$. W orzecznictwie tej Izby jednoznacznie wskazano, że wystarczające jest, aby całokształt okoliczności sprawy w sposób pośredni pozwalał na racjonalne i logiczne wyprowadzenie wniosku, że doszło do zawarcia porozumienia ograniczającego konkurencję ${ }^{24}$. W przepisach prawa zamówień publicznych brak jest podstawy uprawniającej zamawiającego do prowadzenia postępowania mającego na celu zebranie dowodów potwierdzających zawarcie nielegalnej umowy i określającej sposób postępowania zamawiającego w celu ustalenia tych okoliczności. Nie dysponuje on takimi instrumentami jak Prezes Urzędu Ochrony Konkurencji i Konsumentów czy Krajowa Izba Odwoławcza i sądy powszechne. Zamawiający może jedynie oceniać całokształt okoliczności towarzyszących postępowaniu, dokonując zaś oceny faktów, powinien mieć na względzie w szczególności zasady doświadczenia życiowego czy logicznego rozumowania, tak by w sposób prawidłowy ocenić całokształt okoliczności mogących świadczyć o dojściu do zawarcia porozumienia antykonkurencyjnego.

Nadmienić też należy, że wprawdzie prawo zamówień publicznych przewiduje sankcje dla wykonawców zawierających niedozwolone porozumienia, to daje też wykonawcom drugą szansę w tzw. procedurze samooczyszczenia (tzw. instytucja self-cleaning) wprowadzonej przez dokonaną w 2016 r. nowelizację ustawy i przewidzianą w jej art. 24 ust. 8. Zgodnie z tym przepisem wykonawca, który podlega wykluczeniu na podstawie ust. 1 pkt 13 i 20, może przedstawić dowody na to, że podjęte przez niego środki są wystarczające do wykazania jego rzetelności, w szczególności udowodnić naprawienie szkody wyrządzonej przestępstwem lub przestępstwem skarbowym, zadośćuczynienie pieniężne za doznaną krzywdę lub naprawienie szkody, wyczerpujące

${ }^{23}$ Zob. opinia UZP "Jak należy interpretować przesłankę wymienioną w art. 24 ust. 1 pkt 20 ustawy Pzp, o jakie porozumienie chodzi - czy tylko porozumienie w tym postępowaniu, czy także $\mathrm{w}$ innym postępowaniu, w którym doszło do zawarcia takiego porozumienia?" znajdująca się na stronie internetowej Urzędu Zamówień Publicznych, https://www.uzp.gov.pl/baza-wiedzy/interpretacja-przepisow/pytaniai-odpowiedzi-dotyczace-nowelizacji-ustawy-prawo-zamowien-publicznych/ kwalifikacja-podmiotowa-wykonawcow/-jak-nalezy-interpretowac-przeslanke-wymieniona-w-art.-24-ust.-1-pkt-20-ustawy-pzp,-o-jakie-porozumienie-chodzi-czy-tylko-porozumienie-w-tym-postepowaniu,-czy-takze-w-innym-postepowaniu,-w-ktorym-doszlodo-zawarcia-takiego-porozumienia (dostęp: 27 IX 2018).

${ }^{24}$ Zob. np. wyrok KIO z 30 IV 2018 r., KIO 504/18, Legalis nr 1809695; wyrok KIO z 3 III 2014 r., KIO 309/14, Legalis nr 814156; wyrok KIO z 20 VI 2013 r., KIO 1353/13, Legalis nr 738279; wyrok KIO z 23 XII 2013 r., KIO 2851/13, Legalis nr 787363; wyrok KIO z 20 III 2013 r., KIO 517/13, Legalis nr 743547. 
wyjaśnienie stanu faktycznego oraz współpracę z organami ścigania i podjęcie konkretnych środków technicznych, organizacyjnych i kadrowych, które są odpowiednie dla zapobiegania dalszym przestępstwom lub przestępstwom skarbowym bądź nieprawidłowemu postępowaniu wykonawcy. Zamawiający jest uprawniony, uwzględniając wagę i szczególne okoliczności czynu wykonawcy, uznać za wystarczające dowody przedstawione w tym trybie i zaniechać jego wykluczenia.

Fakt, że wykonawcy w postępowaniu o udzielenie zamówienia publicznego złożyli oferty identyczne w zakresie parametrów podlegających ocenie, nie świadczy jeszcze sam w sobie o zawarciu między nimi niedozwolonego porozumienia w celu ograniczenia konkurencji. Może to być jedynie zbieg okoliczności, ale także, w powiązaniu z innymi okolicznościami, symptom świadczący o poczynieniu przez nich takich niezgodnych z prawem uzgodnień. Okoliczności te zamawiający musi $\mathrm{z}$ rozwagą ocenić, albowiem stosując sankcję w postaci wykluczenia wykonawcy lub odrzucenia jego oferty, obowiązany jest udowodnić jego niezgodne $z$ prawem zachowanie.

\section{Podsumowanie}

Zmiany, jakie na przestrzeni lat dokonywane były w prawie zamówień publicznych, począwszy jeszcze od przepisów poprzednio obowiązującej Ustawy z dnia 10 czerwca 1994 r. - Prawo zamówień publicznych ${ }^{25}$, miały na celu odejście od silnie formalistycznego podejścia do zasad sporządzania ofert i ich oceny na rzecz osiągnięcia celu, jakiemu służy postępowanie, i dążenia do wyboru najkorzystniejszej oferty merytorycznie spełniającej wymogi zamawiającego. Wydaje się, że kierunek tych zmian należałoby podtrzymywać, wprowadzając jednoznaczne i niebudzące wątpliwości regulacje dające zamawiającemu możliwość zakończenia postępowania w omawianej sytuacji udzieleniem zamówienia lub w razie braku możliwości dokonania wyboru oferty z powodu złożenia większej liczby ofert w równym stopniu najkorzystniejszych cenowo wyraźnej podstawy do unieważnienia postępowania. Mimo dokonanej w 2016 r. nowelizacji przepisów ustawy w dalszym ciągu niezbędne jest kompletne rozwiązanie problemu wystąpienia identycznych ofert poprzez zawarcie w ustawie norm prawnych określających sposób

\footnotetext{
${ }^{25}$ Tekst jedn. Dz.U. 2002 Nr 72, poz. 664 ze zm.
} 
postępowania przez zamawiającego w sytuacji złożenia identycznych ofert w każdym przypadku, w którym sytuacja taka może wystąpić, oraz w razie braku reakcji wykonawców na wezwanie zamawiającego do złożenia ofert dodatkowych. 